\title{
Field Sampling Plan for the HWMA/RCRA Closure Certification of the TRA-731 Caustic and Acid Storage Tank System
}

\section{Notice of Violation Consent Order}

S. K. Evans

January 2002

Idaho National Engineering and Environmental Laboratory Bechtel BWXT Idaho, LLC 


\title{
Field Sampling Plan for the HWMA/RCRA Closure Certification of the TRA-731 Caustic and Acid Storage Tank System
}

\section{Notice of Violation Consent Order}

\author{
Susan K. Evans
}

January 2002

Idaho National Engineering and Environmental Laboratory Idaho Falls, Idaho 83415

Prepared for the

U.S. Department of Energy

Assistant Secretary for Environmental Management

Under DOE Idaho Operations Office

Contract DE-AC07-99ID13727 


\begin{abstract}
This Field Sampling Plan for the HWMA/RCRA Closure Certification of the TRA-731 Caustic and Acid Storage Tank System is one of two documents that comprise the Sampling and Analysis Plan for the HWMA/RCRA closure certification of the TRA-731 caustic and acid storage tank system at the Idaho National Engineering and Environmental Laboratory. This plan, which provides information about sampling design, required analyses, and sample collection and handling procedures, is to be used in conjunction with the Quality Assurance Project Plan for the HWMA/RCRA Closure Certification of the TRA-731 Caustic and Acid Storage Tank System.
\end{abstract}




\section{CONTENTS}

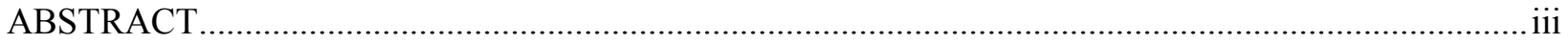

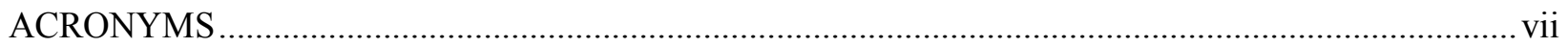

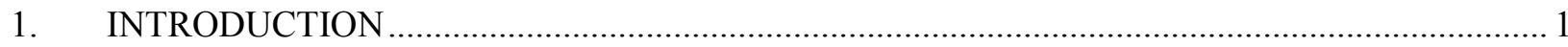

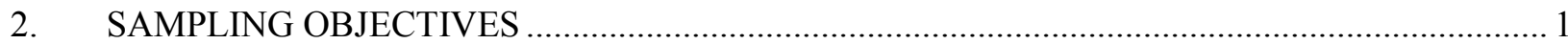

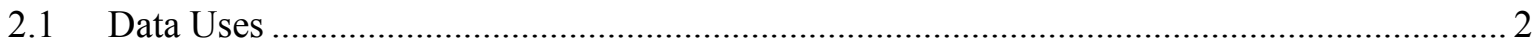

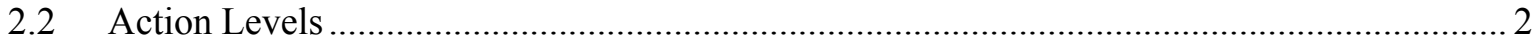

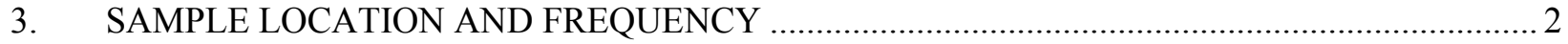

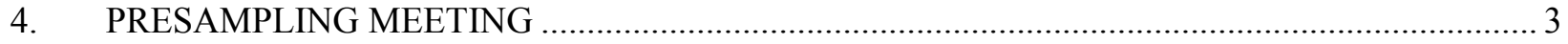

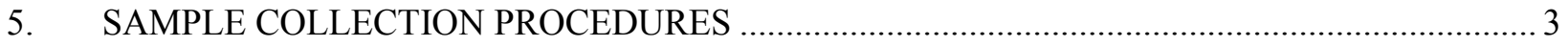

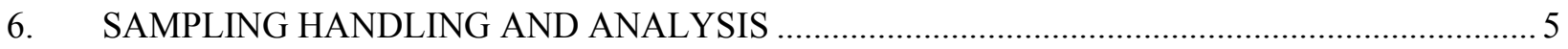

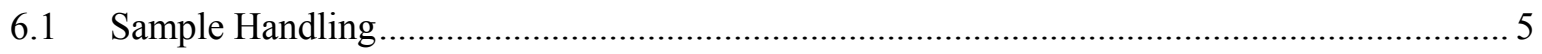

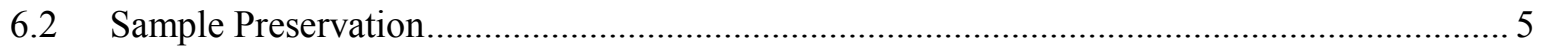

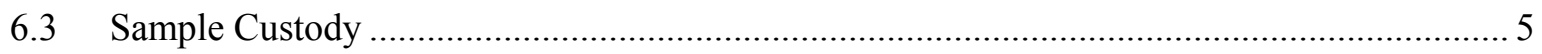

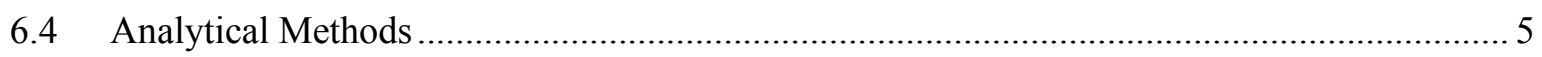

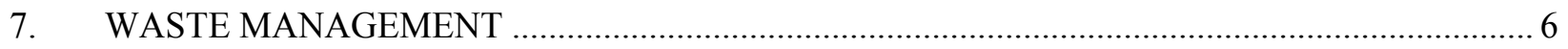

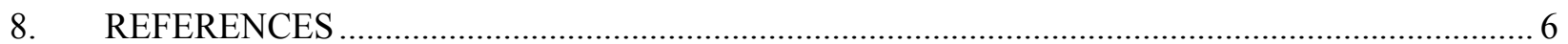

Appendix A-System Schematic

\section{TABLES}

1. Anticipated sample collection for the TRA caustic and acid storage tank system .......................... 3

2. Sample preparation, analytical methods, and method detection limits......................................... 6 


\section{ACRONYMS}

$\begin{array}{ll}\text { AL } & \text { action level } \\ \text { COC } & \text { chain of custody } \\ \text { D\&D } & \text { decontamination and decommissioning } \\ \text { DOE-ID } & \text { U.S. Department of Energy Idaho Operations Office } \\ \text { DQO } & \text { data quality objectives } \\ \text { ESH\&Q } & \text { environment, safety, health, and quality } \\ \text { FSP } & \text { Field Sampling Plan } \\ \text { HDPE } & \text { high-density polyethylene } \\ \text { HWMA } & \text { Hazardous Waste Management Act } \\ \text { IDEQ } & \text { Idaho Department of Environmental Quality } \\ \text { INEEL } & \text { Idaho National Engineering and Environmental Laboratory } \\ \text { QAPjP } & \text { Quality Assurance Project Plan } \\ \text { RCRA } & \text { Resource Conservation and Recovery Act } \\ \text { SAP } & \text { Sampling and Analysis Plan } \\ \text { TPR } & \text { technical procedure } \\ \text { TRA } & \text { Test Reactor Area }\end{array}$




\section{Field Sampling Plan for the HWMA/RCRA Closure Certification of the TRA-731 Caustic and Acid Storage Tank System}

\section{INTRODUCTION}

This Field Sampling Plan (FSP), used in conjunction with the Quality Assurance Project Plan (QAPjP) (INEEL 2001), comprises the Sampling and Analysis Plan (SAP) for the Hazardous Waste Management Act (HWMA)/Resource Conservation and Recovery Act (RCRA) closure certification of the TRA-731 caustic and acid storage tank system.

The TRA-731 caustic and acid storage tank system consists of four product storage tanks, installed in May 1952, that were used to provide caustic and acid product to the water treatment systems at the Test Reactor Area (TRA), Idaho National Engineering and Environmental Laboratory (INEEL). In Fall 1992, the TRA-731 caustic and acid storage tanks were taken out of service; however, the caustic and acid product was not removed from the tanks within 90 days after the tanks were removed from service and the caustic and acid product in the tanks became a waste subject to HWMA/RCRA regulation. The TRA-731 caustic and acid storage tank system includes the TRA-731B and C caustic storage tanks, the TRA-731D and E acid storage tanks, associated fill piping, and associated transfer piping. The storage tanks are located in the fenced area north of the Demineralizer Building (TRA-608), east of TRA-631.

The tank system components to be closed and certified during this sampling effort consist of the four storage tanks. Associated piping and ancillary equipment has been or will be removed as part of past deactivation or under the approved HWMA/RCRA closure plan for the TRA-731 caustic and acid storage tank system. The East/West Trench and associated soils will be addressed under the Federal Facility Agreement and Consent Order.

Bulk wastes were removed from the TRA-731 caustic and acid storage tanks and the tanks rinsed with high-pressure steam in 1998 as part of deactivation activities. The tanks no longer actively manage caustic or acid waste and will be closed under HWMA/RCRA. An HWMA/RCRA closure plan (DOE-ID 2001) has been submitted to the Idaho Department of Environmental Quality (IDEQ) for approval per the 1999 Consent Order resolving the 1997 Notice of Violation (Pisarski 1999). Additional details of the TRA-731 caustic and acid storage tank system and the operational history of the system can be found in the closure plan (DOE-ID 2001).

\section{SAMPLING OBJECTIVES}

The overall purpose of the TRA-731 caustic and acid storage tank system post-decontamination sampling and analysis effort is to demonstrate that tank decontamination activities have resulted in compliance with the HWMA/RCRA closure performance standard (IDAPA 58.01.05.009

[40 CFR 265.111 and 265.197]).

Compliance with the HWMA/RCRA performance standard will be demonstrated by showing that tank rinsate samples (steam condensate) meet contaminant of concern-specific action levels as set out in the HWMA/RCRA closure plan (DOE-ID 2001). Final rinsate samples must be collected and analyzed for a group of parameters to demonstrate performance standard criteria for the tanks have been met. 
There are existing rinsate data for the TRA-731 caustic and acid storage tanks. However, these data cannot be used to support closure certification because only one sample was analyzed from each tank. Previous data collected, coupled with data collected as part of this sampling effort, will be used to determine the disposition of wastes generated during HWMA/RCRA closure activities.

\subsection{Data Uses}

Data from the analysis of the final rinsates from decontamination activities for the TRA-731 caustic and acid storage tanks will be used to demonstrate that decontamination activities meet the performance standard criteria specified in the HWMA/RCRA closure plan (DOE-ID 2001). A detailed discussion of the sampling and data quality objectives (DQOs) can be found in Section 3.1 of the QAPjP (INEEL 2001).

Other activities or programs that may be secondary users of the post-decontamination sampling and analysis data from the TRA-731 caustic and acid storage tanks include:

- $\quad$ Technology development

- Environmental restoration

- $\quad$ TRA operations

- Decontamination and decommissioning (D\&D)

- Corrosion engineering.

Although these projects and programs may be potential users of the data obtained from the post-decontamination characterization efforts, the sampling design is not intended to directly satisfy any data needs for these potential data users. The sampling approach is based on the DQOs specified in the QAPjP (INEEL 2001).

\subsection{Action Levels}

The data are to be used to evaluate several parameters regarding the closure process. Contaminant of concern-specific action levels (ALs) have been established and are provided in Table 5-2 of the HWMA/RCRA closure plan for the TRA-731 caustic and acid storage tank system (DOE-ID 2001). A detailed discussion of the action levels and their development is provided in Appendix A of the HWMA/RCR closure plan (DOE-ID 2001). A detailed discussion of the statistical tests that will be applied to the data obtained from this sampling effort is provided in Section 3.1 of the QAPjP

(INEEL 2001).

\section{SAMPLE LOCATION AND FREQUENCY}

The TRA-731 caustic and acid storage tanks will be decontaminated using high-pressure steam. Decontamination activities will be conducted in such a way that all internal tank surfaces are contacted extensively by the high-pressure steam; the steam condensate (water) collected in the bottom of each tank will be the matrix sampled for closure certification of the TRA-731 caustic and acid storage tank system. Screening-level samples will be used to ensure that the true mean concentration of contaminants of concern are below the established action levels. 
When screening-level samples indicate that the contaminant of concern-specific ALs have been satisfied, each tank will undergo a final decontamination sequence (rinse). Samples for closure certification will be collected from the condensate (water) from each tank in the appropriate sample containers listed in Table 1. Enough sample material will be collected from each of the sampling locations specified in the QAPjP, as shown on Schematic P-CLOS-TRA-731-4 (Appendix A), to fill the number of bottles required to complete the analyses (see Table 1). A minimum of two samples will be collected from each tank. Samples will be collected by placing the peristaltic pump tubing down the centerline of each tank. The tubing will then be pulled to the approximate sampling locations specified on Schematic P-CLOS-TRA-731-4 (Appendix A) and enough sample collected from each sample location to fill a prepreserved (see Section 6.2), 1000-mL high-density polyethylene (HDPE) sample bottle.

Table 1. Anticipated sample collection for the TRA caustic and acid storage tank system.

\begin{tabular}{ccccccc}
\hline Analysis & $\begin{array}{c}\text { Sample } \\
\text { Medium }\end{array}$ & $\begin{array}{c}\text { Sample } \\
\text { Volume } \\
(\mathrm{mL})\end{array}$ & $\begin{array}{c}\text { Number of } \\
\text { Samples per } \\
\text { Tank }\end{array}$ & $\begin{array}{c}\text { Container } \\
\text { Type }\end{array}$ & Hold Time & Preservative \\
\hline Total metals & Water & 1000 & 2 & HDPE bottle & $\begin{array}{c}180 \mathrm{~d} \text {, except } \mathrm{Hg} \\
(28 \mathrm{~d})\end{array}$ & $\mathrm{HNO}_{3}$ to $\mathrm{pH}<2$ \\
\hline
\end{tabular}

a. It is highly recommended that a certificate of cleanliness be obtained for all lots of sample containers used.

Following rinsate sampling of a tank, the peristaltic pump will be completely evacuated of any remaining decontamination solution prior to commencing sampling of the next tank.

\section{PRESAMPLING MEETING}

Prior to sampling, a meeting of project personnel will be held to ensure the sampling and analysis can be performed in a safe manner to provide the project with usable data. Personnel present will include the sampling team, a project quality assurance officer, appropriate health and safety personnel, and project management.

Sampling team members will be experienced in collecting samples. Sampling personnel will be current in their training to the many TRA and INEEL environment, health, safety, and quality (EHS\&Q) procedures and policies.

\section{SAMPLE COLLECTION PROCEDURES}

To ensure that all samples are collected consistently, direction is provided in this section. Tank decontamination and sampling will be performed under a Standard 101 Work Package and Statement(s) of Work.

Sampling of the TRA-731 caustic and acid storage tank rinsates for HWMA/RCRA closure certification will be performed upon completion of tank decontamination efforts (high-pressure steam cleaning). The final rinsate samples (steam condensate) will be collected using a peristaltic pump. The peristaltic pump tubing will be located down the centerline of each tank and samples collected from each of the locations specified on Schematic P-CLOS-TRA-731-4 (Appendix A). Once adequate volume is obtained and placed in the sample container, the tubing will be moved to the next specified sample location. The following is a conceptual overview of the sampling and analysis procedures to be performed 
as part of final rinsate analysis from the TRA-731 caustic and acid storage tank system. Sampling will follow the procedure:

- $\quad$ Decontaminate all tank interior surfaces using high-pressure steam.

- $\quad$ Collect screening-level samples of the steam condensate to ensure that contaminant of concern ALs have been satisfied.

- $\quad$ Based on analysis results, evaluate whether decontamination efforts have satisfied the performance standard (contaminant of concern-specific ALs satisfied) as stated in the HWMA/RCRA closure plan. If the performance standard is not satisfied, perform additional decontamination of the tank and repeat screening level analysis.

- Once screening-level samples indicate that the ALs have been satisfied, complete one additional decontamination cycle.

- $\quad$ Draw required sample volume from the bottom of each tank at the sample locations specified on Schematic P-CLOS-TRA-731-4 using a peristaltic pump and place sample in a prepreserved 1000-mL HDPE sample bottle.

- $\quad$ Prepare quality control samples (see below).

- $\quad$ Transport samples to laboratory for analysis.

- $\quad$ Receive laboratory analysis of sample.

- $\quad$ Obtain independent validation of data.

- $\quad$ Perform data quality assessments on the data to test the statistical hypothesis stated in the DQOs.

- Dispose of spent decontamination solution, as appropriate, based on a completed hazardous waste determination.

Table 1 provides a summary of the samples that are anticipated to be collected during the sampling effort. The table also provides an estimate of the number of anticipated samples, and the anticipated analyses to be requested for each sample.

Quality control samples include field blanks introduced at the appropriate point of the sampling event. Field blanks are analyte-free water that is poured into a sample container at the sample collection site. Field blanks check cross-contamination during sample collection and shipment. Field blanks also provide information on contamination introduced by ambient site conditions. Field blanks are often not collected during waste sampling activities because the very low level of cross-contamination detectable using field blanks would not affect a decision concerning data obtained from measurements on a concentrated waste. However, in the case of this sampling, as the material being sampled is the decontamination rinsate, data concerning cross-contamination may be useful for data interpretation. Therefore, two field blanks will be collected during sampling unless all samples are collected in one day. If sampling is completed in one day, only one field blank will be collected. 


\section{SAMPLING HANDLING AND ANALYSIS}

\subsection{Sample Handling}

Sampling personnel will collect samples in prepreserved, prelabeled 1000-mL HDPE bottles. It is important to collect a sufficient amount of sample to allow for the requested analyses to be performed. Insufficient sample amounts could impact detection limits achieved at the laboratory and, therefore, the ability to make decisions using the data.

\subsection{Sample Preservation}

Sample preservation is conducted to ensure that target analytes do not escape from field samples or become chemically attached to sample containers prior to analysis. Typical sample preservation activities include the addition of acids to ensure that metals remain in solution.

Prior to collecting samples, enough nitric acid $\left(\mathrm{HNO}_{3}\right)$ will be placed in each of the $1000-\mathrm{mL}$ HDPE bottles to bring the $\mathrm{pH}$ of the rinsate to a $\mathrm{pH}<2$. Based on previous decontamination rinsate samples, the $\mathrm{pH}$ of the rinsate is expected to be between 6 and 9 .

After samples have been collected, sampling personnel shall inspect the individual samples to ensure that each sample container has sufficient material to perform the requested analysis. Confirmation that the $\mathrm{pH}$ of each sample is $<2$ will be performed in the field using litmus paper.

\subsection{Sample Custody}

After the appropriate prelabeled sample containers have been filled and the $\mathrm{pH}$ verified, the samples, including field blanks, will be placed in a shipping cooler containing sufficient blue ice to maintain the temperature of the container at approximately $4^{\circ} \mathrm{C}\left( \pm 3^{\circ} \mathrm{C}\right)$. The completed chain of custody (COC) form, prepared by the sampling team member during sample collection, will be taped inside the cooler to document relinquishment of sample custody. Custody seals will then be taped to the shipping cooler to ensure the integrity of the COC between the INEEL and the analytical laboratory.

\subsection{Analytical Methods}

Determinations for inorganic constituents will be performed by the methods presented in SW-846, Test Methods for the Evaluation of Solid Waste, Physical/Chemical Methods (EPA 1986), and the methods listed in Table 3-1 of the QAPjP (INEEL 2001).

Table 2 provides a summary of the analytical requirements for the closure project. Any deviations from these requirements will be fully documented and the project quality assurance officer and/or the project manager will be informed of deviations. 
Table 2. Sample preparation, analytical methods, and method detection limits.

\begin{tabular}{lcccc}
\hline Analysis & $\begin{array}{c}\text { Recommended } \\
\text { Detection Limit } \\
(\mu \mathrm{g} / \mathrm{L})\end{array}$ & $\begin{array}{c}\text { Preparation } \\
\text { Method }\end{array}$ & $\begin{array}{c}\text { Analysis } \\
\text { Method }\end{array}$ & Hold Time \\
\hline Arsenic & 8 & 8 & SW $8466010 \mathrm{~B}$ & $180 \mathrm{~d}$ \\
Barium & 200 & SW-846 3010A & SW 846 6010B & $180 \mathrm{~d}$ \\
Cadmium & 5 & SW-846 3010A & SW 846 6010B & $180 \mathrm{~d}$ \\
Chromium & 10 & SW-846 3010A & SW 846 6010B & $180 \mathrm{~d}$ \\
Lead & 3 & SW-846 3010A & SW 846 7421 & $180 \mathrm{~d}$ \\
Mercury & 0.2 & SW 846 7470A & SW 846 7470A & $28 \mathrm{~d}$ \\
Nickel & 50 & SW-846 3010A & SW 846 6010B & $180 \mathrm{~d}$ \\
Selenium & 5 & SW-846 3010A & SW 846 6010B & $180 \mathrm{~d}$ \\
\hline
\end{tabular}

\section{WASTE MANAGEMENT}

Wastes generated as a result of the post-decontamination characterization of the TRA-731 caustic and acid storage tanks will include laboratory wastes and, potentially, waste generated from decontamination of sampling equipment. Field wastes in the form of paper towels and other wastes associated with sampling activities will be generated. The INEEL Waste Generator Services will ensure that disposition of nonsample waste material is in compliance with all environmental requirements and that applicable paperwork is completed. All samples and analyses wastes will be disposed of in accordance with MCP-2864, "Sample Management."

\section{REFERENCES}

40 CFR 265, "Interim Status Standards for Owners and Operators of Hazardous Waste Treatment, Storage, and Disposal Facilities," Code of Federal Regulations, Office of the Federal Register, July $1,2000$.

DOE-ID, 2001, HWMA/RCRA Closure Plan for the TRA-731B and C Caustic and the TRA-731D and E Acid Storage Tank System, 1997 Notice of Violation Consent Order, DOE/ID-10898, Revision 0, September 2001.

EPA, 1986, Test Methods for Evaluating Solid Waste: Physical/Chemical Methods, Office of Solid Waste and Emergency Response, SW-846, ${ }^{\text {rd }}$ Edition, Revised, 1986.

IDAPA 58.01.05.009, "Interim Status Standards for Owners and Operators of Hazardous Waste Treatment, Storage, and Disposal Facilities," Idaho Administrative Procedures Act, Idaho Department of Environmental Quality Rules, April 5, 2000.

INEEL, 2001, Quality Assurance Project Plan for the HWA/RCRA Closure Certification of the TRA-731 Caustic and Acid Storage Tank System, 1997 Notice of Violation Consent Order, INEEL-EXT-01-01280, Revision 0, October 2001.

MCP-2864, 1999, "Sample Management," Companywide Manual 18—Closure Management, Revision 3, September 3, 1999. 
Pisarski, D. J., IDEQ, to D. N. Rasch, DOE-ID, May 4, 1999, Enclosure: "Signed Consent Order to Resolve the August 25, 1997, Notice of Violation." 


\section{Appendix A System Schematic}


A-2 


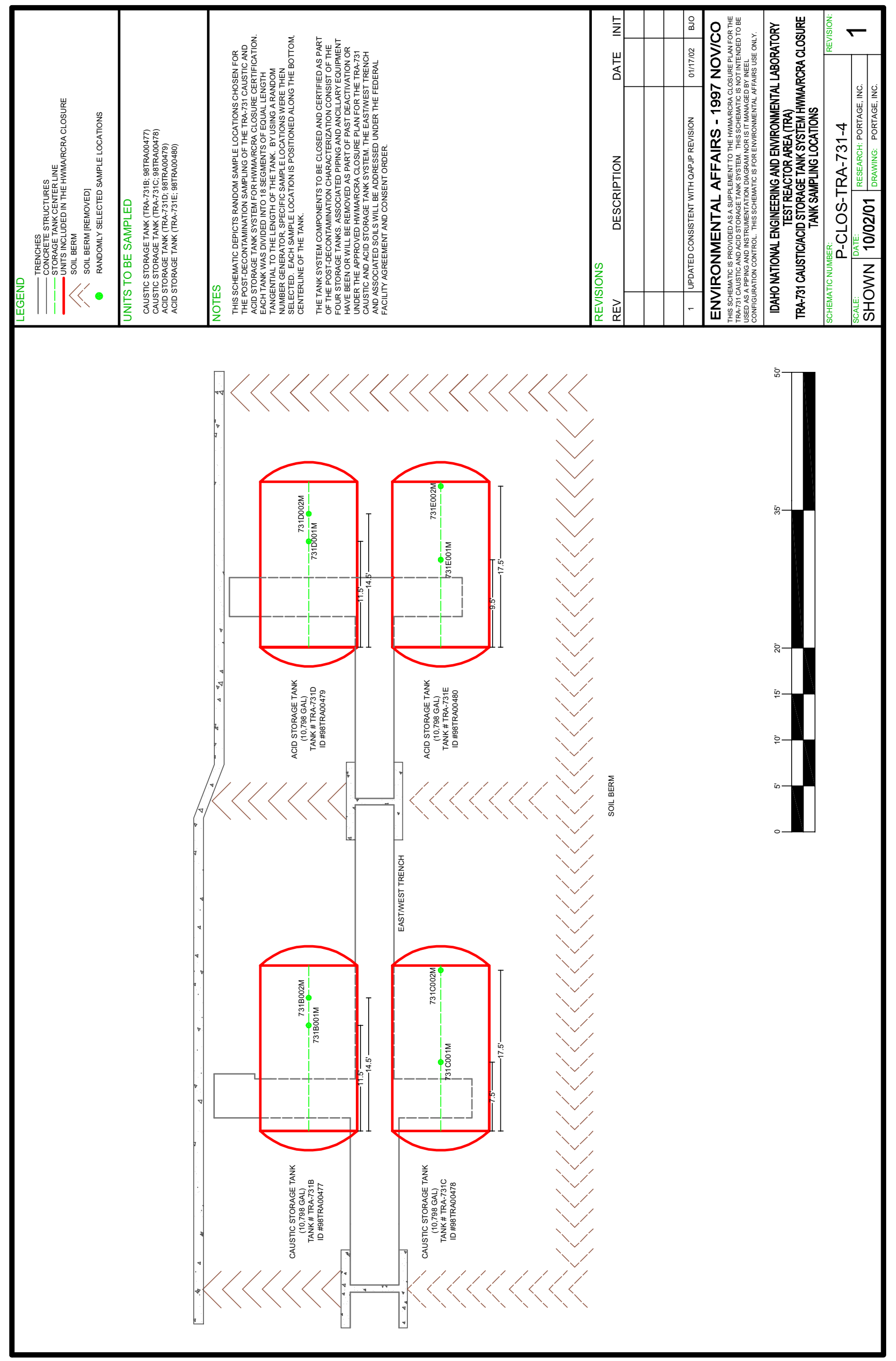

